Teosofia: Indonesian Journal of Islamic Mysticism, Vol. 9, No. 1, 2020, pp. 63-74

e-ISSN: 2540-8186; p-ISSN: 2302-8017

DOI: $10.21580 /$ tos.v9i1.5376

\title{
THE ROLE OF ISLAMIC ART \\ IN ENHANCING THE SPIRITUALITY OF INDONESIAN YOUNG GENERATION
}

\author{
Muhammad Ali Rohmad \\ Universitas Islam Majapahit, Jawa Timur - Indonesia \\ alirohmad86@gmail.com
}

\begin{abstract}
:
Islamic art is radiant beauty of the Islamic spiritual. The young generation must be able to be the front guard in preaching a beautiful religion. The public abandoned Islamic art because it was considered ancient and inferior to the conventional art, which was increasingly innovative. But lately, Islamic art has become popular in Indonesian people again as a phenomenon which is widely discussed, namely the pesantren literary art, represented by the novel Hati Suhita by Khima Anis. While, Islamic music art represented by Sabyan Gambus. As long as Islamic art can maintain quality and continue to innovate, Islamic art can break the dominance of conventional art in Indonesia. With the increasing interest of young people towards Islamic art, of course, it will increase their spirituality.
\end{abstract}

Keyword: Islamic Art, Spirituality, Young Generat5ion, Sabyan Gambus, Hati Suhita

\section{A. Introduction}

$\mathrm{I}$ slam is a religion that was revealed by Allah to all people from the Al-Qur'an, Sunnah, Ijma ' and Qiyas. Islam is a real religion and in accordance with human nature. In the soul, feelings, conscience and human desires contained a love for beauty. Art is abstract, can be seen, heard and touched by the soul but cannot be expressed through words and language. It is difficult to interpret art precisely as hard as it is to explain the concept of beauty itself. Islamic art is part of Islamic culture and the difference between Islamic art and non-Islamic art is in terms of intentions or goals and moral values contained in the results of Islamic art. The achievements made by Islamic art are also Islamic contributions whose purpose is because of Allah. Although art is one of the elements donated, God forbids the creation of art that transcends borders. The Word of Allah swt Al Maidah verse 87 which reads:

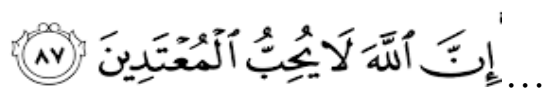

"... Indeed, Allah does not like transgressors." (Surah Al Maidah verse 87) 
The concept of art in Islam is different from other Islamic civilizations, in the development of art, the basic framework should include aspects of morality, faith, and philosophy of human life. Art is a process of education that is positive according to Islamic religion, drives enthusiasm, and awakens morals. This means that art should be amar ma'ruf and nahi munkar, not bringing trouble and also not as a moral destroyer. All activities of human art must be subjected to the ultimate goal of the pleasure of Allah and devotion. All values should be subordinated to relationship with God and the ability to surrender. Art should also be a tool to increase devotion. As the art performed by H. Rhoma Irama, Habib Syech Bin Abdul Qodir Assegaf, Maulana Habib Muhammad Lutfi Bin Ali Bin Yahya, and so forth.

But today in the millennial era, art is often misused according to interests, considered to have no role in increasing the spiritual generation of young people. The issue of neglecting the main source of Islamic arts and culture is none other than the swift influence of cultural works of secular culture and modern society that appear to have been so materialist and biological. The focus of attention and focus of works of art and culture is beauty and outward appearance, no longer sublime and depth of feeling so that vulgar cultural art is born. ${ }^{1}$ While for Muslims who hold fast to the teachings of their religion, they are still struggling with the fear of falling into things that are considered haram in the creation of art. The tension between the shades of Islamic thought with a fiqh pattern which always makes the category of halal and haram with the areas of art and Islamic thought with a style of Sufism that pay more attention to the nature of beauty, so that they can be more appreciative of the local culture and then assimilate it into Islamic thought. ${ }^{2}$ Muhammad Abduh explained that Islamic law never prohibits something beneficial, especially if it is not harmful to religion, faith and charity. ${ }^{3}$

Islamic art and Islamic aesthetics are not ready-made, but rather arenas of debate, conflict and, of course, deep creativity. ${ }^{4}$ Basically, the Al-Qur'an and the Hadith never explicitly explain the principles of aesthetics in artistic expression. This has two logical consequences: First, there is no single Islamic aesthetic concept that can be used as a basis for criticizing all types of Islamic art. Secondly, there is freedom of work and the adoption of concepts and any aesthetic elements into Islamic Fine Arts as long as they do not conflict with the Shari'a. ${ }^{5}$ Therefore several things need to be discussed in this paper including: (1) What is meant by Islamic art and spirituality; (2) How is Spirituality in the frame of Islamic

Bustanuddin Agus, Sosiologi Agama (Padang: Andalas University Press, 2003), 33.

2 M. Amin Abdullah, Pandangan Islam Terhadap Kesenian (Sudut Pandang Falsafah) (Yogyakarta: MKM Universitas Ahmad Dahlan, 1995), 195.

3 M. Abdul Jabbar Beg M., Seni Di dalam Peradaban Islam (Trans) (Bandung: Pustaka, 1988), 63.

4 Kenneth M. Gearge, Melukis Islam: Amal \& Etika Seni Islam Di Indonesia (Bandung: Mizan, 2010), 16.

5 Armahedi Mahzar, Islam Masa Depan (Bandung: Pustaka, 1993), 16. 
art; (3) What is the attitude of the younger generation towards Islamic art; and (4) What is the role of Islamic art in enhancing the spirituality of the younger generation.

\section{B. Overview of Islamic Art}

Art is the expertise to make quality works (in terms of their refinement, beauty, etc.), such as dance, painting, carving. Art includes many human activities in creating visual, audio, or performance works that express the imagination, ideas, or technical skills of the maker, to be valued for their beauty or emotional strength. While art is a part of culture that is triggered by a group of people because every group of people has the nature of love for art that is pleasing through the senses. ${ }^{6}$ Art contains several meanings, (1) expressing aesthetic ideas and thoughts, (2) realizing the ability and imagination of creation (objects, atmosphere, or works that can cause a sense of beauty). (3) realizing one of a number of expressions that are categorized conventionally by the benefits generated or the resulting form (paintings, sculptures, films, dances, works of expression of beauty, crafts and others). ${ }^{7}$ Art is part of human culture. Art as a whole is divided into: pure art and cultural art. Pure art is art that refers more to aesthetics or beauty alone. Art that is used in a special way for various activities, such as: painting, drawing, composing music, or making poetry, which is an activity to produce works, including pure art. Classification of fine art includes: (1) Literary works (poetry, drama, etc.). (2) Fine painting, sculpture). (3) Graphic Art (design). (4) Decorative Arts (furniture design, mosaics). (5) Motion Arts (theater, dance). (6) Art of Music. (7) Architecture. Cultural arts: regarding the expertise to produce something in the form of writing, conversation, and beautiful useful objects. Aesthetic blend with useful uses, such as: objects from pottery, metal crafts, architecture and advertisement design. ${ }^{8}$

Islamic art can also be interpreted as an expression of the beauty of being in terms of the Islamic view of nature, life and humans which leads to a perfect meeting between truth and beauty (according to the origin of nature). ${ }^{9}$ Or with easier language, art is defined as the ability to express aesthetic ideas and thoughts in the creation of objects, atmosphere or works that are able to cause a sense of beauty based on and referring to the Al-Qur' an and Hadith. ${ }^{10}$ Although referring to the basic source of Islam, Islam itself does not determine the form of Islamic art, but only provides references and direction. Therefore Islamic art is not art that originates from a single entity, which is the holy book, but also is closely related to the cultural arts that develop in a society. Art is nature, the ability to be artsy and cultured

\footnotetext{
Sidi Gazalba, Islam Dan Perubahan Sosio Budaya (Jakarta: Pustaka Al-Husna, 1983), 62.

7 Nur Saidah, 'Pendidikan Agama Islam Dan Pengembangan Senibudaya Islam', Jurnal Pendidikan Agama Islam V, No. 1 (2008): 7.

8 Encyclopedia, Ensiklopedia NasionaI Indonesia (Jakarta: Cipta Adi Pustaka, 1989), 525.

9 Quraisy Shihab, Wawasan Al Qur'an (Bandung: Mizan, 1996), 398.

10 Sayyed Hossein Nasr, Spiritualitas Dan Seni Islam, Trans. Sutejo, Islamic Art and Spirituality (Bandung: Mizan, 1993), 14.
}

Teosofia: Indonesian Journal of Islamic Mysticism, Vol. 9, No. 1, 2020 
is one of the differences between humans and other creatures. Then Islam as a religion of nature will support the arts while supporting the nature of the holy man. ${ }^{11}$

At least Islamic art contains three things, (1) reflecting religious values, such as Divine law which specifically has religious elements. (2) Explain spiritual qualities that are polite due to the influence of Sufism values. ${ }^{12}$ (3) There is a subtle and complementary relationship between the mosque and the palace, in terms of the protection, use and function of various arts. Therefore Islamic art is not only related to material materials but also the element of collective religious consciousness that animates these materials. ${ }^{13}$ Thus the art of Islam is not just because it was created by a Muslim but rather because it is based on Divine revelation.

Studying Islamic Art will always have pros and cons. Maybe until now not many people have studied art comprehensively, philosophically (aesthetics or Islamic art philosophy, which formulates the limits of the value of beauty in accordance with Islamic teachings), theoretical (history, structure, and classification: is there Islamic art or is there only Muslim art), practice (the study of field techniques), and appreciation (art criticism that examines the development of Islamic art in relation to the development of Muslim societies) which states that Islamic Art does not exist, and that there are artful Muslims. ${ }^{14}$ Some Muslims or Muslim artists are eager to show various 'aqliyah (rational) propositions that the Al-Qur'an itself contains very high and demonstrative artistic value that the musabaqah tilawatil qur'an (reciting holy Qur'an competition) is held everywhere, as well as the art of Islamic Arabic calligraphy, and naqliyah (text sourced from the Al-Qur'an and as-Sunnah ${ }^{15}$; explain beauty as a work of art. ${ }^{16}$

In the archipelago the influence of Islam in this field of literature gave birth to many poetry prose which explained the greatness of God and praised the Messenger of Allah s.a.w. Literature also plays a role in translating the Al-Qur'an. Many works of art and prose literature were translated into the language of the Indonesian archipelago. Based on the enthusiasm shown by the authors of the Islamic glory, this became a burning spirit of the author in the archipelago to produce more daring work, besides that it also changes the style of language and others. But often the complexity of meaning, where words refer to the same

11 Oliver Leaman, Estetika Islam: Menafsirkan Seni Dan Keindahan, Trans. Irfan Abubakar, (Bandung: Mizan, 2005), 11.

12 Dini Kurniawati, 'The Ethical And Aesthetical Dimension Of Figurative Classical Calligraphy Painting', Teosofia: Indonesian Journal of Islamic Mysticism 5 (2016): 120.

13 Nasr, Spiritualitas Dan Seni Islam, Trans. Sutejo, Islamic Art and Spirituatity, 66.

14 Nanang Rizali, 'Kedudukan Seni Dalam Islam', Jurnal Tsaqafa, Jurnal Kajian Seni Budaya Islam 1, No. 1 (June 2012): 7.

15 Ismail Raji al-Faruqi, Seni Tauhid: Esensi Dan Ekspresi Estetika Islam (Yogyakarta: Bentang Budaya, 1999), 99.

16 M.M Syarif, Iqbal Tentang Tuhan Dan Keindahan (Bandung: Mizan, 1993), 78. 
object, give a different image. ${ }^{17}$

\section{Spirituality in the Frame of Islamic Art}

Spirituality comes from the word spirit which means spirit or soul, or comes from a spiritual word that has an inner or spiritual meaning. Spirituality is a human desire to get closer to the creator. Spirituality is often associated with religiosity, showing the connection between humans and His Holiness, between the concrete and the abstract, and between humans and God. As such, spirituality is specifically associated with conventional measures of religiosity such as closeness to God, the foundation of belief, and religious practice. Spirituality is realized in the abstract aspects of human life that underlies a part of something that has a true essential that makes itself religious.

Broadly speaking, seen the source and process of spiritual occurrence or spiritual values that are believed and practiced consists of three types of spiritual teachings, namely: 1) Spiritual heteronomy. In this spiritual style, seekers or spiritual practitioners tend to accept, understand, believe or practice spiritual references (spiritual values) that come from external authorities. Practitioners of spiritual teachings in heteronomy are obeying and accepting their meaning and validity in the form of submissive actions in the sense of simply accepting, believing and practicing, without having to reflect or rationalize the meaning of the teachings.

2) Autonomous spirituality, which is a form of spirituality that originates from the results of reflection from itself. This spiritual style is self-contained and independent of external authority, which is generated from within oneself and free from outside authority. Autonomous spirituality is actually a spiritual value that is produced by the process of reflection on the greatness of God and his creation.

3) Interactive spirituality, namely the spiritual or spiritual value that is formed through an interactive process between himself and his environment. Thus, this spiritual style is not absolute because of internal and external factors. However, it is more the result of a dialectical process between the spiritual potential (mental, feelings, and morals) on the one hand and external authority in the form of tradition, the way of society, and the world order around it. ${ }^{18}$

Spiritual values exist in Islamic art, Sayyed Husein Nasr discusses the fields of art in the perspective of spirituality. The fields of art in question include literature and music. Art in Islam is also closely related to holiness, namely purity that appears in the form of beautiful writings which are often referred to as calligraphy. The field of literature, occupies an important position in Islamic art. Because the literature includes Islamic teachings sourced from Allah SWT which is manifested in a series of holy verses and manifested in

17 Deddy Mulyana, Ilmu Komunikasi (Bandung: Rosdakarya, 2014), 383.

18 Mircea Eliade, The Encyclopedia of Religion (New York: Macmillan, 1993), 321.

Teosofia: Indonesian Journal of Islamic Mysticism, Vol. 9, No. 1, 2020 
the form of the Holy Qur'an. In literature also contains poetry, which is a combination of spiritual and intellectual principles in the material and substance of language. A very beautiful example of poetry in Islam is Al-Barzanzi's poem, which is a poem used to give praise to the Messenger of Allah. ${ }^{19}$

In the field of music, music is a field that has an important meaning in the view of Islamic spirituality. Among the forms of music that can be connected with Islamic spirituality are forms of classical music that are very closely related to Sufis, because basically Sufis use music as a means to pacify the soul and a means to cure diseases both physically and spiritually. The music used for these things is certainly music that has a high spiritual value. When humans listen to music, then in the end music will bring people to peace and tranquility that is hidden in its center. Humans will be able to find their own spiritual truth, as Hayy Ibn Haqzan in Ibnu Thufail's romantic religious philosophical philosophy. But the challenge for educational experts and practitioners is how spiritual concepts can be actualized practically. ${ }^{20}$

\section{Indonesian Young Generation}

The current generation of young people or young Indonesians is commonly referred to as the millennial generation. Youth are also often referred to as future leaders. The term millennial generation laying stones is the first two historians and American writers William Strauss and Neil Howe. Millennials also in some sources are demographic groups after generation $\mathrm{X}$ (Gen $\mathrm{X})$. There is no time limit on the beginning and end of this generation. Researchers usually use the size from births in the early 1980s to the 2000s as the end of births of the millennials, that is, the average millennial generation is 13 - 35 years old.

Millennial generation stamps are usually pinned to those who are too busy with cyberspace, as well as being considered an instant generation. The generation that wants to progress but does not want to struggle. There is nothing wrong with the accusation. The internet, smartphones and gadget-like items cannot be denied nowadays have become basic necessities. They are naturally infatuated with technological developments. It's just that, the Smartphone does not necessarily make us smart. Sometimes our intelligence is trapped defeated by smartphones, so that we are close to feel far, and far away feels close. This is, our social intercourse is limited by the intelligence of gadgets so that we look stupid around friends, relatives, and even our own family. ${ }^{21}$

With advances in technology as it is today, literary art and music art among the younger generation is sometimes difficult to control, then the young generation must be the

19 Nasr, Spiritualitas Dan Seni Islam, trans. Sutejo, Islamic Art and Spirituality, 45.

20 Syaikhu Rozi, 'Melacak Jejak Spiritualitas Manusia Dalam Tradisi Islam Dan Barat', Jurnal Tarbiya Islamia, Ejurnal.Unim.Ac.Id. Vol. VII Nomor 2 (Agustus 2018): 20.

21 Aswad Mahasin, 'Santri: Generasi Millenial Vertikal', NU Online, 30 September 2017, 3. 
vanguard of preaching a shady Islam, not chaos. The young generation must become promoters of unity, peace and order. Instead of being a provocateur, hostility, slander and expressions of hatred. The young generation must continue to be historical actors, not the burden of history and must be able to take on the role as a locomotive of social change for the benefit of the people, not just a driver. ${ }^{22}$

But furthermore, now is starting to enter a new era that is getting heavier namely the disruptive era. The disruptive era occurred because new innovations entered the market and created a disruption effect that was strong enough to change the structure of the previous market, for example the phenomenon of base taxi bike with online taxi bike. Likewise with positive art and negative art one after the other shifts. Therefore, today's art must be encouraged to educate the young generation to become millennial-vertical generation. That is, art that is always related to his Lord (Hablum Minallah), away from His prohibitions and carrying out His commands. Not only that, we must also be educated to be a millennial-horizontal generation, where our art is directed to benefit the togetherness and brotherhood (Hablum Minannas). ${ }^{23}$

The young generation as future leaders must really be able to continue the struggle of the current leader. We can imagine if today's youth is not qualified, how can they lead the future of Indonesia. So it is not wrong if someone says that if we want to see a country in the future, we can look at youth today. History records various achievements of Indonesian young generation in various fields such as sports, arts, academics, technology, and other fields. Therefore, the young generation must be able to harmonize the affairs in the world and the hereafter in a balanced manner, so that it becomes a reliable young generation.

The younger generation is synonymous with art that comes from abroad. Moreover, arts and culture from the outside increasingly shifted the arts and culture in the country. Therefore, the young generation must continue to study traditional arts and culture which are feared to be engulfed by the ages. So there is no longer a generation of young people who do not know our own art and culture. In addition, many things can make the younger generation no longer passionate about learning traditional arts and culture, one of which is the declining quality of local language culture. Then the next task for the younger generation is to improve the quality of arts and culture in the country.

\section{E. The Role of Islamic Art in Enhancing Spirituality}

Islamic art is recognized or not, has contributed to the development of young generation spirituality. Between art and spirituality has a very close relationship, this can be seen from various fields of art that are very closely related to spirituality, in other words that

22 Yunisca Nurmalisa, Pendidikan Generasi Muda (Yogyakarta: Media Akademi, 2017), 37.

23 Muhammad Ali Rohmad, 'Seni Islam Di Era Millennial', Snp2m.Unim.cc.id, no. Prosiding SNP2M (2019): 221. 
Islamic art is a manifestation of Islamic spirituality, this close relationship can be seen from the way Muslims do activities religious ritual activities such as prayer and dhikr. Islamic art cannot be separated from Islamic spirituality, because Islamic art contains the intention to convey the divine message of God. ${ }^{24}$ Although Islamic art is directly inspired by Islamic spirituality, its form is still shaped by the socio-cultural character that surrounds it. It's just that these characters do not reduce the truth and inner content and spiritual dimensions of Islam that are the source of Islamic art. ${ }^{25}$

Islamic art is no different from other arts that contain many functions, Islamic art contains special functions. ${ }^{26}$ Islamic holy arts contain at least four spiritual messages or functions. First, flowing blessings as a result of his inner connection with the spiritual dimension of Islam. Second, remind the presence of God wherever humans are. Third, it becomes a criterion to determine whether a social, cultural and even political movement is truly authentic Islamic or only uses the symbol of Islam as a slogan to achieve certain goals. Fourth, as criteria for determining the level of intellectual and religious relations of Muslim societies. Art should be drawn in a positive direction and in harmony with Islamic spirituality. As a phenomenon which has been recently discussed by the millennials, the pesantren literary art is represented by the novel Hati Suhita written by Khima Anis. While the art of music represented by Nissa from Sabyan Gambus music.

Islamic art has indeed been abandoned by the public because it is considered ancient and inferior to conventional art which is increasingly innovative. But the art of Islam is again in demand by the people of Indonesia as a new phenomenon. The social media universe dominated by the younger generation, especially the Facebook timeline has recently been enlivened by the appreciation of the novel "Hati Suhita" by Khilma Anis. Those who are interested in obtaining the novel must be willing to queue pre-orders, because the stock is always out. In the world of literature, especially those with a typical pesantren background, the novel Hati Suhita is worthy of being filmed. ${ }^{27}$

The novel Hati Suhita was originally a serialized story written on the facebook wall, but in fact it kidnapped the hearts of its readers. The novel Hati Suhita is one of the novels by Khilma Anis after JPN (Jadilah Purnamaku Ning) and Wigati. He is a pesantren alumni who has been actively joining the magazine writing community since school. Khilma Anis's works neatly feature figures from pesantren backgrounds and noble Javanese traditional values. The novel Hati Suhita raised the polemic of Alina Suhita's life as a tough woman who harbored feelings towards her husband's cold attitude, Gus Birru. The story of the inner struggle between obtaining rights as a woman as well as her obligations as a wife. This

24 Nasr, Spiritualitas Dan Seni Islam, Trans. Sutejo, Islamic Art and Spirituality, 56.

25 Siti Binti A.Z, 'Spiritualitas Dan Seni Islam Menurut Sayyed Hossein Nasr', Jurnal Harmonia, Universitas Negeri Semarang 6 (2005): 4.

26 The Liang Gie, Garis Besar Estetik (Filsafat Keindahan) (Yogyakarta: Supersukses, 1983), 47.

27 Ali Usman, 'Fenomena Suhita: Kebangkitan Sastra Pesantren?', Alif.Id (blog), 28 April 2019. 
drama was added with a third party, Ratna Rengganis, who had long filled the hearts and days of Gus Birru. The inner atmosphere throughout the story is enriched with Javanese philosophical values taken from wayang and chronicle stories, also alluding to philosophy and the world of student movements. This characterizes Khilma Anis's writing style compared to other writers. Editor of Hati Suhita, Akhiriyati Sundari, considered that what was written by Khilma Anis, a pesantren novel full of Javanese values but also packaged in popularity was a new thing. Different from Islamic novels or other religious novels which have boomed, this novel is more appropriate to represent the life of a pesantren. The value of gender is very gender pesantren. It means that the management of pesantren is more prominent by women leaders. $^{28}$

While in the art of music, Nissa Sabyan makes surprises that color the history and development of religious music in Indonesia. Nissa Sabyan was viral, the song was loved by many people, including the younger generation who are usually less interested in such music. The popularity achieved by Nissa and Sabyan even made the production house Millenia Pictures interested in bringing their music journey to the big screen through the film titled "Sabyan Menjemput Mimpi" which aired in theaters on June 27, 2019. History of Religious Music in Indonesia Before being introduced by groups or singers such as Bimbo, Rhoma Irama, Nasida Ria, Opick, Sulis and Haddad Alwi, to Sabyan Gambus in the present era, religious music in Indonesia already has a long history. Quoted from a book by title Kekuatan Musik Religi; Mengurai Cinta Merefleksi Iman, Menuju Kebaikan Universal (2010) written by Indriya R Dani and Indri Guli, religious music in Indonesia began to be introduced by Wali Songo as a disseminator of the teachings of Islam in the archipelago since the 14th (fourteenth) AD. The song Tombo Ati, which was successfully brought back by Aunur Rofiq Lil Firdaus (Opick), also the song Lir-ilir, his poem was written by Wali Songo as a means of propagating Islam in the Javanese community. ${ }^{29}$

Religious music with the beat of the gambus is not only heard at Islamic religious events. Sabyan Gambus is able to break the image of gambus music that seems oldfashioned, monotonous and (even) boring into a modern and entertaining musical presentation. The Sabyan Gambus phenomenon is a shock to everyone. There has never been a Gambus music group that has such popularity as Sabyan Gambus. During this time the public knows the gambus music group as a group of people who sing shalawat songs without ever knowing the personnel of the gambus music group. Everything has changed since the presence of Sabyan Gambus. Sabyan Gambus Instagram followers are more than two million people, even the vocalist Khoirunissa or known as Nissa Sabyan has more than thirteen million followers. Sabyan Gambus has succeeded in doing something that everyone has not expected; bringing gambus music through the dominance of pop and dangdut music

28 Nur Hanifah, 'Hati Suhita: Merawat Literasi Sastra Pesantren', www.nu.or.id (blog), 1 April 2019.

29 Alexander Haryanto, 'Sabyan Gambus Sempat Menjadi Fenomena Dan Viral Di Jagat Musik Indonesia', https://tirto.id/eim (blog), 19 September 2019. 
in the Indonesian music industry. ${ }^{30}$ Even the video song of the blessing of Ya Maulana (some of the lyrics: Dengan Kasih-Mu Ya Robbi, berkahi hidup ini; Dengan cinta-Mu Ya Robbi, damaikan mati ini...), managed to penetrate the number 322 million views. This is an extraordinary achievement because it rarely happens video clips from Indonesian religious musicians who penetrate the numbers as achieved by them.

At every event, Khilma Anis and Nissa Sabyan would be crowded with fans in attendance. This is one indicator that Islamic art is stretching again. This is a golden opportunity to inject a positive spiritual virus through Islamic art. The closer the young generation to Islamic art, the closer they will be to the spiritual of Islam. So it is clear that Islamic art has an important role in enhancing the spirituality of Indonesia's young generation. As long as Islamic art always strives and can maintain quality and continue to innovate, it is possible for Islamic art to break the dominance of conventional art in Indonesia. Especially in such a desolate era, intense competition will surely occur. But we must be sure, because belief is half of success, then increasing the interest of Indonesian young generation towards Islamic art must be done, of course this will increase their spirituality as well.

\section{F. Conclusion}

From the discussion above it can be concluded that Islamic art is part of Islamic culture, and the difference between Islamic art and others is in terms of intentions (goals) and moral values contained in the results of Islamic art. God forbid the creation of art that transcends borders. so it takes the name spirituality in art. Spiritual is a human desire to get closer to the creator. Between art and spirituality has a close relationship. Art should be drawn in a positive direction and in harmony with Islamic spirituality. The younger generation is the leader of the future must be able to become the front guard in preaching a peaceful and beautiful Islam.

The role of Islamic art in enhancing the spirituality of Indonesia's young generation is very important, as Islamic art is revived as the phenomenon which is widely discussed is the pesantren literary art represented by the novel Hati Suhita by Khilma Anis. While the Islamic music art represented by Nissa from the Gambus Sabyan group. They have made the good young generation who have "pesantren character". As long as Islamic art can maintain quality and continue to innovate, it is possible for Islamic art to break the dominance of conventional art in Indonesia. With the increasing interest of the younger generation towards Islamic art, of course it will increase their spirituality, because Islamic art contains spiritual value.

30 Gijayana Putri, 'Fenomena Sabyan Gambus Yang Mampu Mendobrak Image Musik Gambus Menjadi Kekinian', www.bhasafm.co.id (blog), 25 July 2018. 


\section{Bibliography}

Abdullah, M. Amin. Pandangan Islam Terhadap Kesenian (Sudut Pandang Falsafah). Yogyakarta: MKM Universitas Ahmad Dahlan, 1995.

Agus, Bustanuddin. Sosiologi Agama. Padang: Andalas University Press, 2003.

Binti A.Z, Siti. 'Spiritualitas Dan Seni Islam Menurut Sayyed Hossein Nasr'. Jurnal Harmonia, Universitas Negeri Semarang 6 (2005).

Eliade, Mircea. The Encyclopedia of Religion. New York: Macmillan, 1993.

Encyclopedia. Ensiklopedia NasionaI Indonesia. Jakarta: Cipta Adi Pustaka, 1989.

Faruqi, Ismail Raji al-. Seni Tauhid: Esensi Dan Ekspresi Estetika Islam. Yogyakarta: Bentang Budaya, 1999.

Gazalba, Sidi. Islam Dan Perubahan Sosio Budaya. Jakarta: Pustaka Al-Husna, 1983.

Gearge, Kenneth M. Melukis Islam: Amal \& Etika Seni Islam Di Indonesia. Bandung: Mizan, 2010.

Gie, The Liang. Garis Besar Estetik (Filsafat Keindahan). Yogyakarta: Supersukses, 1983.

Hanifah, Nur. 'Hati Suhita: Merawat Literasi Sastra Pesantren'. Www.Nu.or.Id (blog), 1 April 2019.

Haryanto, Alexander. 'Sabyan Gambus Sempat Menjadi Fenomena Dan Viral Di Jagat Musik Indonesia'. Https://Tirto.Id/Eim(blog), 19 September 2019.

Jabbar Beg M., M. Abdul. Seni Didalam Peradaban Islam (Terj). Bandung: Pustaka, 1988.

Kurniawati, Dini. 'The Ethical And Aesthetical Dimension Of Figurative Classical Calligraphy Painting'. Teosofia: Indonesian Journal of Islamic Mysticism 5 (2016).

Leaman, Oliver. Estetika Islam: Menafsirkan Seni Dan Keindahan, Terj. Irfan Abubakar, Bandung: Mizan, 2005.

Mahasin, Aswad. 'Santri: Generasi Millenial Vertikal'. NU Online, 30 September 2017.

Mahzar, Armahedi. Islam Masa Depan. Bandung: Pustaka, 1993.

Mulyana, Deddy. Ilmu Komunikasi. Bandung: Rosdakarya, 2014.

Nasr, Sayyed Hossein. Spiritualitas Dan Seni Islam, Trans. Sutejo, Islamic Art and Spirituatity. Bandung: Mizan, 1993.

Nurmalisa, Yunisca. Pendidikan Generasi Muda. Yogyakarta: Media Akademi, 2017. 
Putri, Gijayana. 'Fenomena Sabyan Gambus Yang Mampu Mendobrak Image Musik Gambus Menjadi Kekinian'. WWw.Bhasafm.Co.Id(blog), 25 July 2018.

Rizali, Nanang. 'Kedudukan Seni Dalam Islam'. Jurnal Tsaqafa, Jurnal Kajian Seni Budaya Islam 1, No. 1 (June 2012): 7.

Rohmad, Muhammad Ali. 'Seni Islam Di Era Millennial'. Snp2m.Unim.Ac.Id, no. Prosiding SNP2M (2019).

Rozi, Syaikhu. 'Melacak Jejak Spiritualitas Manusia Dalam Tradisi Islam Dan Barat'. Jurnal Tarbiya Islamia, Ejurnal.Unim.Ac.Id. Vol. VII Nomor 2 (Agustus 2018).

Saidah, Nur. 'Pendidikan Agama Islam Dan Pengembangan Senibudaya Islam'. Jurnal Pendidikan Agama Islam V, No. 1 (2008).

Shihab, Quraisy. Wawasan Al Qur'an. Bandung: Mizan, 1996.

Syarif, M.M. Iqbal Tentang Tuhan Dan Keindahan. Bandung: Mizan, 1993.

Usman, Ali. 'Fenomena Suhita: Kebangkitan Sastra Pesantren?' alif.id (blog), 28 April 2019. 